\title{
底泥の化学組成および粒度分布を用いた底泥輸送の推定 一京浜運河への適用事例 -
}

\author{
Estimation of the Spatial Distribution of Sediment \\ Using Chemical Composition and Particle-size Distribution
}

\author{
岡田知也 ${ }^{1} \cdot$ グェンティーモンチン ${ }^{2} \cdot$ 古川恵太 ${ }^{1}$
}

\author{
Tomonari OKADA, Nguyen Thi Mong Trinh and Keita FURUKAWA
}

\begin{abstract}
We present a method to estimate the spatial distribution of sediment by using chemical composition and particle-size distribution. We applied the method to samples of sediment from Keihin Unga, Tokyo Bay, Japan. The chemical composition was analyzed by wavelength dispersive X-ray spectrometry. For particle-size analysis, organic matter was removed from sediment using $\mathrm{H}_{2} \mathrm{O}_{2}$. The spatial distribution of chemical composition and sediment removed organic matter showed clearly the distribution of impacts of sediments from the Tama River and Tokyo bay. The result demonstrates the feasibility of the method to reduce uncertainty in interpreting the spatial distribution of impacts of sediment from some sources.
\end{abstract}

\section{1. はじめに}

近年，多くの沿岸域において自然再生事業が行われて いる。 その代表的な技術メニューとして, 覆砂や干潟造 成が挙げられる。これらの共通点は, 砂を主体とした生 物生息基盤を造ることである.よって, その生物生息基 盤の持続可能性の観点では, 砂の供給がある水域の方が 有利だと考えられ, また, 自然再生場所として比較的に 適していると考えられる. 現状ではたとえ砂の供給より も有機物の沈降量の方が勝っていたとしても, 将来的に 水質が改善され有機物の沈降量が少なくなった場合に, 砂 の供給がある場所か否か（砂の供給の潜在的な能力があ るか否か）は, 長期的な視点で自然再生場を選定する際 に重要な情報だろう。そして，その砂はどこから運ばれ てくるかの情報も, 生息基盤の空間的ネットワークとし て重要である。

砂をはじめとする海域の底泥の輸送に関しては，これ まで多くの研究がなされている. 特に, 近年の数值モデ ル発展は, 様々な検討を可能にしている. ところが, 数 值モデルにおいて常に問題となるのは境界条件データの 不足であり, 境界条件データが揃い難い水域や現象の計 算は困難である。したがって, 何らかの底泥指標から底 泥の輸送を推定する技術は，依然として重要であろう.

推定においては, 互いに独立な指標が多い程, 推定の 精度は向上する. そのため, 新たな底泥輸送のトレーサ 一となり得る底泥の指標の開発は重要である. そこで本

$\begin{array}{lll}1 \text { 正会員博 (工) } & \text { 国土技術政策総合研究所 沿岸海洋研究 } \\ & \text { 部 海洋環境研究室 } \\ & \text { 東京工業大学大学院総合理工学研究科 } \\ & \text { 環境理工学創造専攻 }\end{array}$

研究では, 底泥輸送の推定に寄与する新しい指標として 底泥の化学組成および粒度分布を提案する.

化学組成は, 地質および岩石鉱物等の分野でこれまで 用いられてきたが（例えば，味喜ら，2003；新正，2002）, 環境の視点から沿岸域や内湾の底泥に対して適用された 事例は極めて少ない。化学組成は, 鉱物の成因に依存す る. そのため, 海域で化学組成を比較する際には, 種々 の成因からなる底泥を含む広域な範囲の方が有利であろ う.しかし, 本研究では敢えて比較的狭い領域である京 浜運河（川崎一横浜）に適用した（図-1). 本水域の流動 に影響を及ぼす多摩川, 鶴見川, 工業地帯特有の多くの 工場排水, 下水排水および発電所排水の時間変動は一定 ではなく，また排水量デー夕の入手が困難である。 その ため, 本水域では数值モデルを用いて長期の底泥輸送を 計算することが極めて困難である.つまり, この様な数 值モデルの適用が困難な場所での本手法の適用性が確か められれば，本手法の応用範囲は格段に広がるだろう。

粒度に関するデータは, 既往の研究で多く使われてい るが, 多くの場合, 中央粒径, ソート度, 含泥率等の粒 度分布を $1 つ の$ 指標に集約した值（以後，統計值と呼ぶ） として用いられている. 一方, 近年の技術発展により, こ れまで篩を用いて測定していた粒度分布が，レーザ式粒 度分布測定装置によって容易に測定できるようになった。 加えて, その装置に必要な試料の量は, 高々数 $\mathrm{g}$ 程度であ る. その結果, 分析および採泥に対する労力は従来に較 ベて格段に軽減し, 多地点の粒度分布を得ることが可能 になった. しかし，その多地点の粒度分布データを解析・ 表現する手法が無いため, せっかく得られた粒度分布デ ー夕の統計值のみしか使われていないのが現状である.

Forrest ・ Clark（1989）はこの問題を解決するために, 


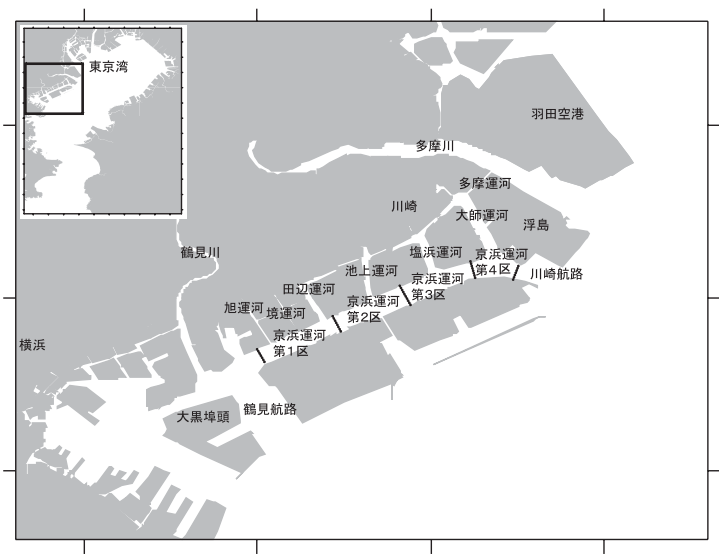

図-1 京浜運河およびその周辺運河の位置と名称

情報理論分野で確立されたEntropy Analysis（Shannon, 1963）を粒度分布に適用する手法を提案した（以後，エ ントロピー法と呼ぶ)。この手法は，グループ化において 粒度分布の全体形状を直接使うため, 統計值を使った解 析と較べて粒度分布が持つ情報量の損失が小さい利点が ある。

加えて，粒度の測定に関しては，別の問題がある．富 栄養化した底泥の強熱減量は $10 \%$ 程度に及び，鉱物粒子 と有機物の密度差を考慮すると，有機物は体積割合で約 $20 \%$ に及び，無視できる割合ではない．鉱物粒子のみの 粒度分布を得たい場合には，有機物を除去する必要があ ると考える。

これらのことから, 本研究は, 底泥輸送の推測に寄与す る新しい底泥指標として, 底泥の化学組成および有機物を 除去した底泥の粒度分布を提案することを目的とする.

\section{2. 調查手法}

\section{(1) 採泥}

2007 年の 12 月に京浜運河周辺水域において, 164 地点 の採泥を行った（図-1，採泥地点は図-2等を参照）。採泥 はエクマン・バージ型採泥器を用いて船上から行った．東 京湾湾奥における底泥堆積速度が約 $1 \mathrm{~cm} / \mathrm{y}$ （日本海洋学会 編，1986）であることを考慮し，季節的な底泥輸送では なく数年スケールの底泥輸送を検討するために，採取さ れた底泥の表層 $5 \mathrm{~cm}$ を試料とした。

\section{(2) 化学組成}

化学組成分析には，波長分散型蛍光X線装置（Rigaku， Supermini）を用いた（閉歳，2008）。本装置は，軽元素 （F）から重元素（U）まで測定可能である．蛍光X線装置 による分析は，ICP発光分析装置と比べて低濃度の分析に は向かないが，前処理に化学的処理を必要としない利点 がある。

分析は $63 \mu \mathrm{m}$ 以下のシルト分と $63 \mu \mathrm{m}$ 以上の砂分に対し
て行った．底泥をシルト分と砂分に分けた理由は2つあ る. 1 つは粗粒子による吸着物質の希釈効果を排除するた めである（Homensら，2006）。例えば，重金属は，粗粒 分より細粒分に強く吸着するため，周囲水中の重金属濃 度が同じであっても，シルト分が多い底泥の方が濃度は 大きく，粗粒分が多い底泥の方が濃度は小さくなってし まう．2つ目の理由は，シルトと砂の輸送形態が異なるこ とから，輸送範囲が異なることが想定されたためである.

その他の分析用試料の前処理および分析手法等は，後 藤・巽（1991）に従った，なお，ここで示す值は，検量 線を用いた定量值ではなく半定量值であるので，ここで の議論は地点間の相対的大小を論るに留める.

\section{(3) 粒度分布}

粒度分布の測定にはレーザ回折・散乱式粒子径分布測 定装置（LA-950，堀場製作所製）を用いた。粒度分布の 区分は表-1の粒度区分とした。分析対象は，特別の処理 をしていない底泥（未処理底泥）と有機物を除去した底 泥の 2 種類である.

測定に際し，有機物やイオン効果等によって凝集して いる塊を分散させるために，超音波を照射し（約 30 秒）， 粒度分布が安定した後に測定した。

有機物の除去には，30\%過酸化水素水 $\left(\mathrm{H}_{2} \mathrm{O}_{2}\right)$ を用い た (Poppeら, 2003 ; Mikuttaら, 2005). 5g の底泥に対して $30 \mathrm{ml}$ の $\mathrm{H}_{2} \mathrm{O}_{2}$ を加え, $90{ }^{\circ} \mathrm{C}$ の湯浴を 1 時間行った後に，遠

表-1 粒度分布測定装置による粒径区分. N：区分番号， G： 粒径 $(\mu \mathrm{m}), \mathrm{L}$ ：粒径の対数表示.

\begin{tabular}{r|c|c|c|c|c|c|c|c}
\hline $\mathrm{N}$ & $\mathrm{G}$ & $\mathrm{L}$ & $\mathrm{N}$ & $\mathrm{G}$ & $\mathrm{L}$ & $\mathrm{N}$ & $\mathrm{G}$ & $\mathrm{L}$ \\
\hline 1 & 1.0 & 0.00 & 21 & 15.2 & 1.18 & 41 & 229.1 & 2.36 \\
\hline 2 & 1.2 & 0.06 & 22 & 17.4 & 1.24 & 42 & 262.4 & 2.42 \\
\hline 3 & 1.3 & 0.12 & 23 & 19.9 & 1.30 & 43 & 300.5 & 2.48 \\
\hline 4 & 1.5 & 0.18 & 24 & 22.8 & 1.36 & 44 & 344.2 & 2.54 \\
\hline 5 & 1.7 & 0.24 & 25 & 26.1 & 1.42 & 45 & 394.2 & 2.60 \\
\hline 6 & 2.0 & 0.30 & 26 & 29.9 & 1.48 & 46 & 451.6 & 2.65 \\
\hline 7 & 2.3 & 0.36 & 27 & 34.3 & 1.53 & 47 & 517.2 & 2.71 \\
\hline 8 & 2.6 & 0.41 & 28 & 39.2 & 1.59 & 48 & 592.4 & 2.77 \\
\hline 9 & 3.0 & 0.47 & 29 & 44.9 & 1.65 & 49 & 678.5 & 2.83 \\
\hline 10 & 3.4 & 0.53 & 30 & 51.5 & 1.71 & 50 & 777.1 & 2.89 \\
\hline 11 & 3.9 & 0.59 & 31 & 59.0 & 1.77 & 51 & 890.1 & 2.95 \\
\hline 12 & 4.5 & 0.65 & 32 & 67.5 & 1.83 & 52 & 1019.5 & 3.01 \\
\hline 13 & 5.1 & 0.71 & 33 & 77.3 & 1.89 & 53 & 1167.7 & 3.07 \\
\hline 14 & 5.9 & 0.77 & 34 & 88.6 & 1.95 & 54 & 1337.5 & 3.13 \\
\hline 15 & 6.7 & 0.83 & 35 & 101.5 & 2.01 & 55 & 1531.9 & 3.19 \\
\hline 16 & 7.7 & 0.89 & 36 & 116.2 & 2.07 & 56 & 1754.6 & 3.24 \\
\hline 17 & 8.8 & 0.95 & 37 & 133.1 & 2.12 & 57 & 2009.7 & 3.30 \\
\hline 18 & 10.1 & 1.00 & 38 & 152.5 & 2.18 & 58 & 2301.8 & 3.36 \\
\hline 19 & 11.6 & 1.06 & 39 & 174.6 & 2.24 & 59 & 2636.5 & 3.42 \\
\hline 20 & 13.2 & 1.12 & 40 & 200.0 & 2.30 & 60 & 3000.0 & 3.48 \\
\hline & & & & & & & &
\end{tabular}


心分離して上澄水を捨てた。この工程を 3 回繰り返して, 分析用の試料とした。

多地点の粒度分布は，エントロピー法によってグルー プ化された．手法の詳細は岡田ら（2009）に示している ので，ここでは省略する.

\section{3. 結果}

\section{（1）化学組成}

a) シルト分

化学組成分析では, 岩石の平均的な組成である $\mathrm{SiO}_{2}$, $\mathrm{Al}_{2} \mathrm{O}_{3}, \mathrm{Fe}_{2} \mathrm{O}_{3}, \mathrm{CaO}, \mathrm{K}_{2} \mathrm{O}, \mathrm{MgO}, \mathrm{MnO}, \mathrm{Na}_{2} \mathrm{O}, \mathrm{P}_{2} \mathrm{O}_{5}$, $\mathrm{TiO}_{2}$, 人為的附加と考元られる $\mathrm{CuO}, \mathrm{ZnO}, \mathrm{Cr}_{2} \mathrm{O}_{3}$, その 他 $\mathrm{Br}, \mathrm{Cl}, \mathrm{SO}_{3}, \mathrm{SrO}$ 等が検出された。 ここでは, $\mathrm{SiO}_{2}$,
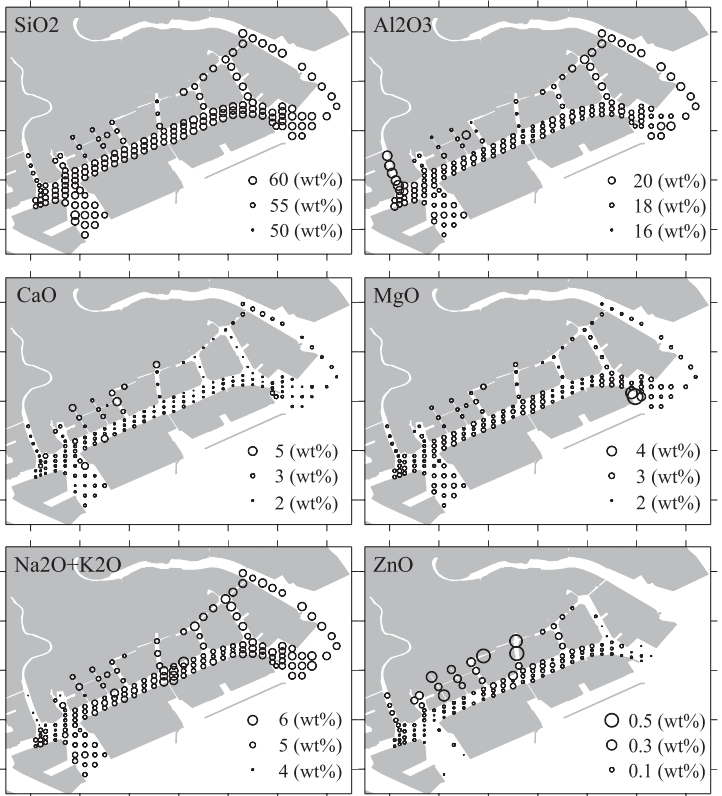

図-2 シルト分の化学組成の平面分布

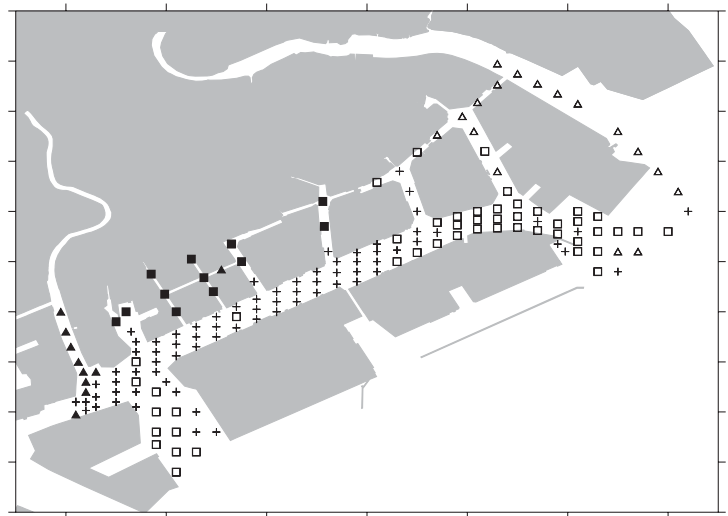

図-3 シルト分の化学組成に対するクラスター分析によるグ ループの平面分布図. $\triangle$ : 領域 $1, \square$ : 領域 $2,+$ : 領 域 3 ,
$\mathrm{Al}_{2} \mathrm{O}_{3}, \mathrm{CaO}, \mathrm{MgO}, \mathrm{Na}_{2} \mathrm{O}+\mathrm{K}_{2} \mathrm{O}$, 人為的附加と考えられ る $\mathrm{ZnO}$ を一例として示す（図-2).

$\mathrm{SiO}_{2}$ は多摩川河口，大師運河，川崎航路および鶴見航 路で比較的に高かった. $\mathrm{Al}_{2} \mathrm{O}_{3}$ は多摩川河口, 大師運河, 川崎航路入口，鶴見航路および鶴見川河口で高い值だっ た. 鶴見川河口で $\mathrm{Al}_{2} \mathrm{O}_{3}$ が高い值だったことが， $\mathrm{Al}_{2} \mathrm{O}_{3}$ と $\mathrm{SiO}_{2}$ が大きく異なった点だった.アルカリ岩の指標であ る $\mathrm{Na}_{2} \mathrm{O}+\mathrm{K}_{2} \mathrm{O}$ は多摩川河口, 大師運河, 塩浜運河, 京浜 運河第2区，京浜運河第4区および川崎航路で高かったが, 鶴見川河口では低かった。（以後，京浜運河に対しては， 区名のみ記す.）周辺工場の影響（人為的附加）と考えら れる $\mathrm{ZnO}$ は, 鶴見川河口, 旭運河, 境運河, 田辺運河, 池 上運河，塩浜運河および第2区で高かった。逆に，多摩川
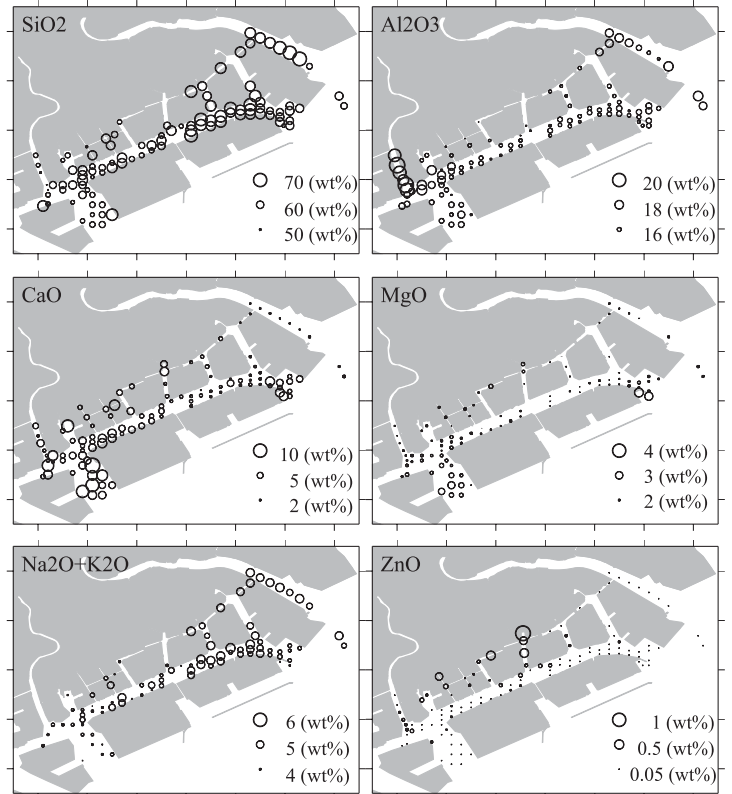

図-4 砂分の化学組成の平面分布

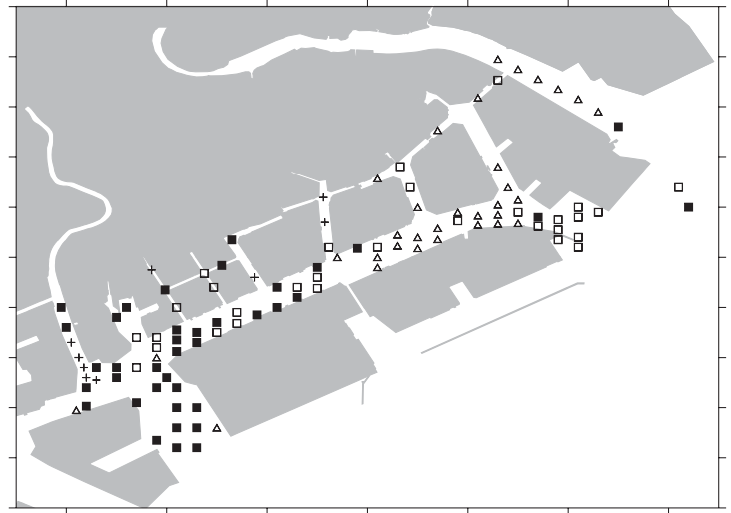

図-5 砂分の化学組成に対するクラスター分析によるグルー プの平面分布図. $\triangle$ : 領域 $1, \square$ : 領域 $2, \square$ : 領域 $3,+$ : 領域 4. 
河口, 大師運河, 川崎航路および鶴見航路では低かった.

人為的附加と考えられる $\mathrm{ZnO}$ を除いた $\mathrm{SiO}_{2}, \mathrm{Al}_{2} \mathrm{O}_{3}$, $\mathrm{Fe}_{2} \mathrm{O}_{3}, \mathrm{MgO}, \mathrm{CaO}, \mathrm{K}_{2} \mathrm{O}, \mathrm{Na}_{2} \mathrm{O}$ に対してクラスター分析 （ウォード法）を行い，全地点を5つのグループに分割し た（図-3）。領域(1)：多摩川河口および大師運河，領域 (2)：川崎航路，第4区および鶴見航路，領域(3)：鶴見川河 口沖, 第1-3区, 塩浜運河, 領域(4): 旭運河, 境運河, 田 辺運河，池上運河，領域(5)：鶴見川河口に分割された.

b) 砂分

砂分の対しては, $63 \mu \mathrm{m}$ 以上の粒子量が少ないため, 分 析が出来なかった地点があった（51 地点）（図-4）.

$\mathrm{SiO}_{2}$ は，多摩川河口，大師運河，塩浜運河，第3区，第 4区，川崎航路で高く，鶴見川河口では低かった（図-4). $\mathrm{Al}_{2} \mathrm{O}_{3}$ は鶴見川河口および多摩川河口で高かった. $\mathrm{Na}_{2} \mathrm{O}+$ $\mathrm{K}_{2} \mathrm{O}$ は多摩川河口，大師運河，塩浜運河，第3区，第4区 で高かった. $\mathrm{CaO}$ は $\mathrm{Na}_{2} \mathrm{O}+\mathrm{K}_{2} \mathrm{O}$ の分布とは逆に鶴見航路, 鶴見川河口沖㧍よび第1区で高かった。

シルトと同じ化学組成に対してクラスター分析を行い, 全地点を4つのグループに分割した（図-5)。領域(1)：多 摩川河口，大師運河，第3区，第4区，領域(2)：川崎航路, 領域(3)：鶴見川河口沖，第1区，第2区，鶴見航路，領域 (4)：鶴見川河口，池上運河に分割された。シルト分と比 較すると，異なるグループが混在する領域が多かった．

\section{(2) 粒度分布}

エントロピー法を用いて，未処理底泥と有機物が除去 された底泥をそれぞれ4つのグループに分割した（図-6, 7). 各地点によって程度の大小はあるが，有機物が除去 されると，粒度分布はシルト成分が相対的に減少し，砂 成分が相対的に増加した。

川崎航路や第2区，池上運河，鶴見川河口は，有機物が 除去されても依然としてシルトが卓越する粒度分布だっ た（図-6，7)。一方，鶴見航路，第3区，第4区，大師運

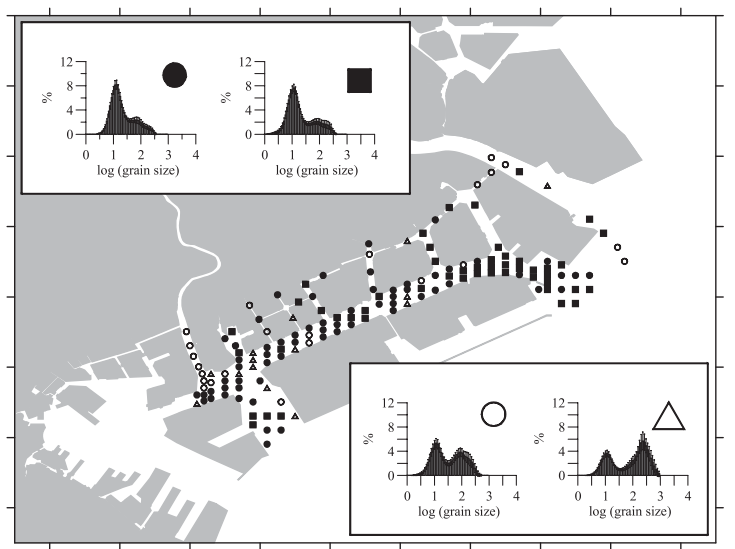

図-6 未処理底泥のグループ化. : A1, $\mathrm{A} 2, \bigcirc: \mathrm{A} 3$ $\triangle:$ A 4 .

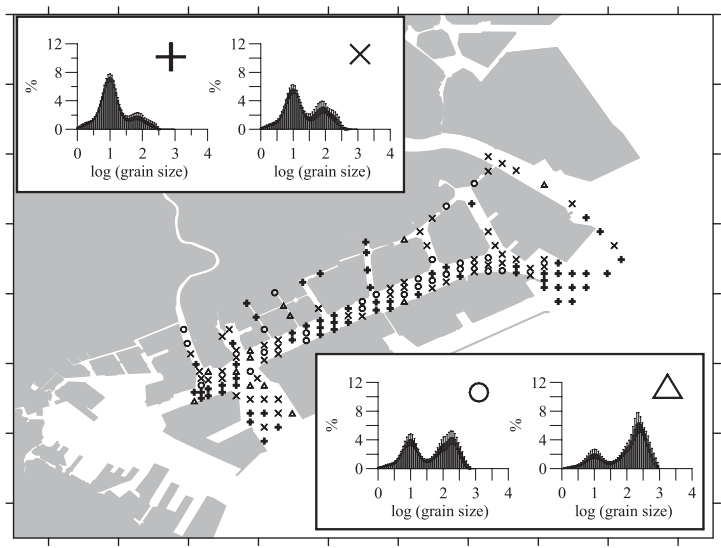

図-7 有機物処理底泥のグループ化. + : B1, $\times: \mathrm{B} 2, \bigcirc$ : B3, $\triangle:$ B 4 .

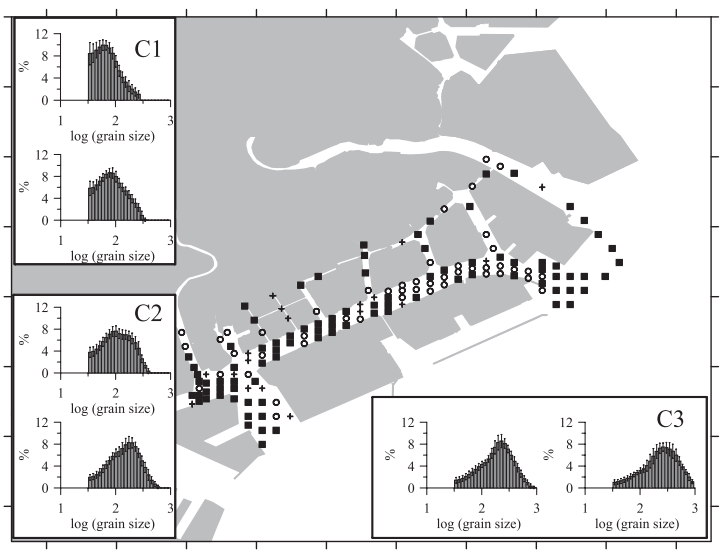

図-8 有機物処理底泥の $35 \mu \mathrm{m}$ 以上の成分に対するグループ 化. $\mathrm{\square} \mathrm{C} 1, \bigcirc: \mathrm{C} 2,+\mathrm{C} 3$.

河，塩浜運河は，砂のモードが明瞭になり，極細砂混じ りのシルトや中砂混じりのシルトになった。

この有機物が除去されたことによって明瞭になった砂 分のモードサイズの違いを明らかにするため，シルト分 と砂分のモードの谷に相当した $35 \mu \mathrm{m}$ 以上の粒度分布を， エントロピー法によって6つのグループに分割した（図8).さらに，これら6つのグループは，モードサイズが, $60 \mu \mathrm{m}$ 程度の $\mathrm{C} 1,100-200 \mu \mathrm{m}$ 程度の $\mathrm{C} 2,250-300 \mu \mathrm{m}$ 程度の C3に大きく3つにまとめられた．C1は鶴見川河口沖，鶴 見航路，第1区，第2区，川崎航路抒よび多摩川河口沖側 に主に分布した。C2は多摩川河口の上流側，大師運河， 第3区，第4区に主に分布した。そして，C3は全域に点在 した.

\section{4. 考察}

京浜運河周辺のシルト分は，大きく5つに分けられるだ ろう (図-3)。領域(1)：多摩川河口，大師運河，領域(2)： 
川崎航路, 第4区，鶴見航路，領域(3)：鶴見川河口沖から 第1-3区, 塩浜運河, 領域(4)：池上運河, 田辺運河, 境運 河，旭運河，そして領域(5)：鶴見川河口である.

領域(1は，同じ化学組成を持つグループが多摩川から 多摩運河を通じて大師運河に拡がっていることから, 多 摩川の影響範囲と考えられる。そして，その影響範囲は 大師運河までと言えるだろう。領域(2)は, $\mathrm{Al}_{2} \mathrm{O}_{3}$ および

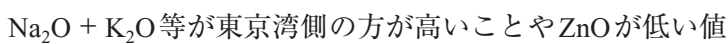
であることから，東京湾の影響と考えられる．ここで，東 京湾の影響とは，多摩川や鶴見川以外の河川から東京湾 に流入した鉱物が東京湾の流れを経由して京浜運河内に 達することを意味する．領域(3)は，化学組成が領域(2)と 領域(4)の中間的な值を示すこと, および分布範囲が $\mathrm{ZnO}$ の京浜運河内での分散範囲と類似していることから, 元 は領域(2)と同様に東京湾の影響であるが領域(4)の影響を 受けて別のグループとして分けられたと考えられる. 領 域(5は鶴見川の影響範囲であろう。予想に反して, 鶴見 川の影響範囲は鶴見川河口のみに限定されていた。

次に，砂分について考察する，化学組成に基づく領域 区分（図-5）とモードサイズに基づく領域区分（図-8）は, 良く一致した。これらから，砂分は大きく3つに分けられ るだろう。領域 (1)：多摩川河口, 大師運河, 第3区, 4区, 領域(2)：川崎航路, 領域(3)：鶴見航路, 第1区, 第2区で ある。

この砂の領域区分は，シルト分の領域区分とは異なっ ており, 同じ場所でもシルト分と砂分は異なる由来の影 響を受けていることを示すだろう。多摩川の影響範囲は, 大師運河を通じて第3 区，第4区に及んでいると考えられ る.川崎航路を通じた東京湾の影響は, 川崎航路までで あろう。第4区では，シルト分は東京湾の影響であるが, 砂分は多摩川の影響であると言える。一方，砂分の鶴見 航路を通じた東京湾の影響は, 鶴見航路から第 1 区，第2 区まで及んでいると考えられる。

次に，量に関して考察する。東京湾の影響と考えられ る川崎航路の砂分の量は, 粒度分布に扔いてシルトが卓 越していることから（図-7，B1）, シルト分と比較して相 対的に非常に少ないだろう。また，第2区は鶴見航路およ び第1区と同様に東京湾からのシルト分と砂分の影響を受 けている領域であるが, その構成比率は鶴見航路㧍よび 第1区とは異なりシルト分が大きい. 第2区に到達する砂 分の量は少ないか, もしくは堆積するシルト分の量が多 いと考えられる.

\section{5. おわりに}

底泥の輸送範囲を推定する新たな指標として, 化学組 成および有機物を除去した底泥の粒度分布の使用を，京 浜運河周辺海域で試みた。化学組成分析結果は, 異なる 由来の底泥の影響範囲を推定するのに十分明暸な空間分 布を示した。また，有機物を除去した底泥の粒度分布は， 富栄養化した海域において底泥輸送と粒度分布を結びう ける上で有用な手法であることが示された。これらの手 法は, まだ途上段階であり, 解析手法等に工夫の余地は あるものの, 底泥輸送の特徴を把握する上で, 今後に有 用な手法になり得るだろう。

謝辞 : 本研究を進めるにあたり, 東京工業大学大学院総 合理工学研究科石川忠晴教授には有益な助言を頂いた。 また, 本研究の一部は, 科学研究費基盤研究 (C) (課題 番号：20560483, 研究代表者：岡田知也）の支援によっ て実施された。ここに記して感謝の意を表します。

\section{参 考 文 献}

岡田知也・グェンティーモンチン・古川恵太（2009）：粒度 分布形状に基づいた底泥分布図の提案 一東京湾を例と して - , 海洋開発論文集, 第34卷, pp.401-406.

閑歳浩平 (2008) : 蛍光 X線分析法による岩石の分析, リガ クジャーナル, Vol.39 (1), pp.31-39.

後藤 篤・巽 好幸 (1991) : 蛍光X線分析装置による岩石 試料の定量分析 (I), 理学電気ジャーナル, Vol.22, pp.28-60.

新正裕尚・折橋裕二 - 角井朝昭 - 中井俊一 (2002) : 室生火 砕流堆積物の全岩化学組成：その給源への手掛り, 岩石 鉱物科学, Vol.31, pp. 307-317.

日本海洋学会編 (1986) : 沿岸環境調查マニュアル[底質・生 物篇], 恒星社厚生閣, $266 \mathrm{P}$.

味喜大介・宇都浩三・周藤正史・石原和弘（2003）：古地磁 気と全岩化学組成からみた兴島火山観測井ボーリングコ ア中の溶岩の対比, 京都大学防災研究所年報, 第 46 号 B.

Forrest, J., N.R. Clark (1989): Characterizing grain size distribution: evaluation of a new approach using a multivariate extension of entropy analysis, Sedimentology Vol.36, pp. 711-722.

Homens, M. M., R. L. Stevens, F. Abrantes and I. Cato (2006): Heavy metal assessment for surface sediment from three areas of the Portuguese continental shelf, Continental Shelf Research Vol.26, pp. 1184-1205.

Mikutta, R., M. Kleber, K. Kaiser, and R. Jahn (2005), Organic matter removal from soils using hydrogen peroxide, soidim hypochlorite, and disodium peroxodisulfate, Soil Science Society of America, Vol.69, pp. 120-135.

Poppe, L. J, A.H. Eliason, J. J. Fredericks, R. R. Rendigs, D. Blackwood and C. F. Polloni (2003): Grain-size analysis of marine sediments: methodology and data processing, U.S. Geological Survey Openfile Report, http://pubs.usgs.gov/of/2000/of00-358/text/chapter1.htm, 参照 2009-05-19.

Shannon, C.E.(1963): The mathematical theory of communi cation, University of Illinois Press, Urbana. 